\title{
КОНЦЕПТУАЛЬНІ ПІДХОДИ ДО РОЗРОБКИ ПРОГРАМИ НАУКОВИХ ДОСЛІДЖЕНЬ У ФІЗИЧНОМУ ВИХОВАННІ
}

\author{
О.М. Худолій, О.В. Іващенко \\ Харківський національний педагогічний університет \\ ім. Г.С. Сковороди
}

Педагогічні ситуації, що постійно змінюються, вимагають від учителя не тільки знання типових рішень, але і постійного пошуку нових способів. Більш того, знайдені вчителем оригінальні способи рішення педагогічної задачі повинні стати надбанням інших учителів, а для цього необхідно вміти аналізувати отримані результати й оформляти їх. Реалізувати всі ці вимоги можна тільки в тому випадку, якщо вчитель буде озброєний методологією педагогічних досліджень у фізичному вихованні, тобто системою знань і умінь в галузі підготовки і проведення педагогічного дослідження, обробки, аналізу і представлення результатів дослідження.

За своєю суттю педагогічне дослідження у фізичному вихованні відноситься до теоретикоприкладного і виконується за розробленою програмою $[1 ; 2 ; 3 ; 4 ; 5 ; 6]$.

Програма дослідження - це виклад його концепції у відповідності до мети і гіпотези дослідження 3 вказівкою методик збору і аналізу даних, а також послідовності операцій для 1 перевірки.

Повна програма дослідження має такі структурні елементи.

Методологічний розділ програми:

1. Формулювання проблеми, визначення об’єкта і предмета дослідження.

2. Визначення мети і постановка завдань дослідження.

3. Уточнення й інтерпретація основних понять.

4. Попередній системний аналіз об'єкта дослідження.

5. Розгортання робочих гіпотез.

Процедурний розділ програми:

6. Принциповий план дослідження.

7. Обгрунтування кількісного складу піддослідних.

8. Перелік основних процедур збору і аналізу даних.

Проблема, визначення об'єкта і предмета дослідження. Вихідним пунктом педагогічного дослідження є проблемна ситуація, в якій виділяється гносеологічна і предметна складова.

3 точки зору пізнавального процесу (гносеологічна складова) проблемна ситуація - це «знання про незнання, невідповідність або протиріччя між знанням про потреби людей у результативних практичних або теоретичних діях і незнанням шляхів, засобів, методів, спо- собів, прийомів реалізації цих необхідних дій» (П.В. Копнин, М.В. Попович).

Предметна складова проблеми педагогічного дослідження - це постійно присутнє протиріччя між очікуваним результатом спортивної діяльності і способом його досягнення; між бажанням особистості досягти максимального результату й існуючими в даний конкретний час способами його досягнення. Проблема характеризується недостатністю наявної інформації для вирішення конкретних завдань фізичного виховання.

Предметна і гносеологічна складова педагогічного дослідження взаємопов'язані. В самому простому випадку - це недостатня обізнаність вчителя про проблемну ситуацію внаслідок чого неможливе використання вже набутих знань для ii розв'язання.

Формулювання проблеми тягне за собою визначення об'єкта дослідження. Об'єкт педагогічного дослідження - це те, на що спрямований процес пізнання. Іншими словами - це все те, що явно чи неявно містить протиріччя, породжує проблемну ситуацію і створює проблему.

Предмет дослідження - це найважливіші 3 практичної або теоретичної точок зору властивості, особливості об'єкта, що підлягають вивченню.

Наскільки об’єкт - те, що містить проблему, настільки предмет - це його властивості і сторони, які утворюють полюса протиріччя між способом досягнення результату і результатом.

Розглянемо для прикладу, як формулюється проблема, об’єкт і предмет дослідження при вивченні ефективності навчання гімнастичним вправам юних гімнастів 8-10 років. Проблема цього дослідження - протиріччя між процесами засвоєння і забування. Об'єкт дослідження - режими навчання гімнастичним вправам. В цьому об'єкті міститься протиріччя. Предмет дослідження - співвідношення між кількістю повторень і інтервалом відпочинку і їх вплив на формування рухової навички. Так, повторення вправи 2-3 рази в підході 3 інтервалом 180 с призводить до забування (Є. Біндусов), а скорочення інтервалу відпочинку до 60 с формує втому і знижує рівень навченості (О. Іващенко). Тож треба дати відповідь на питання, які чинники впливають на ефективність навчання і який режим навчання є оптимальним. Це питання є иентральним і пов'язується з припущенням про шляхи вирішення проблеми. 
Постановка центрального питання - джерело висунення робочих гіпотез.

Отже, формулювання проблеми, виділення об’єкта і предмета дослідження перший крок в розробці програми.

Визначення мети і завдань дослідження. Мета дослідження орієнтує на кінцевий результат, який визначає загальну спрямованість і логіку дослідження. Завдання формулюють запитання, на які потрібно отримати відповіді для реалізації мети дослідження. Вони розкривають зміст предмета дослідження.

Мета і завдання дослідження утворюють одне ціле. Визначення мети дослідження дає можливість упорядкувати процес наукового пошуку у вигляді послідовного розв'язування поставлених завдань.

Наприклад:

Мета дослідження - визначити вплив різних режимів виконання гімнастичних вправ на процес навчання юних гімнастів 8-10 років.

Завдання дослідження:

1. 3'ясувати як впливають інтервал відпочинку і кількість повторень на формування рухової навички у юних гімнастів 8-10 років.

2. Визначити вплив функціонального стану юних гімнастів 8-10 років на процес навчання гімнастичним вправам.

3. Розробити методику оптимізації режиму навчання гімнастичним вправам юних гімнастів 8-10 років.

Завдання дослідження класифікуються на основні, часткові і додаткові. Основні і часткові завдання логічно зв'язані, часткові завдання витікають із основних і є засобами рішення головного питання дослідження. Додаткові завдання - ставляться 3 метою підготовки майбутніх досліджень, перевірки гіпотез не пов'язаних 3 даною проблемою.

Вся процедура дослідження підкоряється пошуку відповіді на центральне питання. Програмні мета і завдання дослідження дисциплінують роботу і підвищують ㄲï ефективність.

Уточнення i iнтерпретація основних понять. Для педагогічного дослідження важливим $є$ пошук емпіричних значень понять, які використовуються в роботі. Цей процес називають емпіричною інтерпретацією.

При розробці програми педагогічного дослідження в першу чергу виділяються ключові поняття, що виражають вузлові моменти досліджуваної проблеми. Саме вони і піддаються емпіричній інтерпретації, що дозволяє не тільки сформулювати, але і перевірити гіпотези на базі фактичних даних.

Увесь процес інтерпретації понять ділиться на три послідовних етапи:

- операціоналізація понять, яка передбачає пошук інструментарію для виміру емпіричних референтів;
- теоретична інтерпретація понять, яка передбачає наукове визначення;

- емпірична інтерпретація понять, яка передбачає пошук емпіричних показників теоретичних понять.

Послідовність дій при уточненні основних понять, інтерпретації їхнього змісту в показниках, що спостерігаються, зводиться до:

- аналізу відповідної літератури з предмета дослідження, уточнення змісту понять у рамках даного теоретичного підходу;

- вибору прямих показників кожної з виділених характеристик, тобто перехід до операційних уточнень: якими конкретними методами i технічними прийомами можна зафіксувати виділені властивості.

При зворотному русі до аналізу даних відповідно до висунутих гіпотез украй важливо ще раз перевірити (тепер уже спираючись на досвід, отриманий при зборі даних і вивченні іхніх зв’язків), наскільки семантична й емпірична інтерпретації ключових понять дослідження були задовільними, тобто якою мірою можливі прямі співвіднесення показників і індексів з тим змістом, властивостями, до яких вони спочатку були «прив'язані».

Рух від теорії до уточнення змісту й емпіричної інтерпретації основних понять дослідження, як і повернення до теоретичного тлумачення отриманих даних - це складний пізнавальний процес, в якому важливу роль грають аналогії, асоціації, наукова інтуїція, знання і досвід дослідника, його загальна культура.

Попередній системний аналіз об'єкта дослідження. В процесі інтерпретації основних понять окреслюється емпірична область, що відповідає визначеному предмету дослідження.

Наступним кроком роботи є системний аналіз об’єкта дослідження, в процесі якого об'єкт розчленовується на елементи, які зв'язуються в гіпотетичну систему.

Попередній системний аналіз предмета дослідження - це «моделювання» дослідницької проблеми, тобто таке ii концептуальне розчленування і деталізація, які дозволяють сформулювати загальні і часткові гіпотези дослідження.

Розгортання робочих гіпотез. Гіпотеза - головний методологічний інструмент, що організовує увесь процес дослідження і підкоряє його суворій логіці.

Гіпотеза - це обгрунтоване припущення про можливі способи розв'язання визначеної проблеми. Для того, щоб її сформулювати, треба добре знати об'єкт дослідження. Лише за умови старанного вивчення характерних рис педагогічних явищ можна висловити гіпотетичне положення, яке вимагає подальшої перевірки. Воно висувається як своєрідний висновок про існування проблеми, педагогічних суперечностей, їх при- 
чин. Причому у формулюванні висновку мають чітко проглядатися ті положення, які необхідно доводити і захищати. Те, що й так ясно, не є гіпотезою, бо iï цінність значною мірою визначається нестандартністю, невідповідністю знанням, котрі вже широко відомі в теорії та практиці педагогіки.

Логічна конструкція гіпотези являє собою умовно-категоричний умовивід «Якщо..., то...». Перша посилка висуває умову, а друга затверджує наслідок з даної умови. Якщо дослідження не підтверджує наслідок, гіпотеза спростовується, але підтвердження наслідку не дає логічних основ для вірогідності гіпотези. Підтвердження робить гіпотезу правдоподібною, ймовірною. Звідси одна з принципових вимог до гіпотези: чим більш наслідків вона містить, тим більш ймовірно її підтвердження.

Тому для підвищення вірогідності гіпотетичного судження варто керуватися правилами: (а) прагнути до висування можливо більшого числа взаємозалежних гіпотез і (б) прагнути вказати для кожної гіпотези можливо більше число ii емпіричних індикаторів (референтів).

У педагогічних дослідженнях використовуються такі види гіпотез:

- основні гіпотези вказують на найсуттєвіші зв'язки об'єкта;

- гіпотези-наслідки виводяться 3 основних і служать засобом їх доказу;

- робочі гіпотези висуваються на початкових етапах аналізу іє вихідними даними щодо характеру і властивостей досліджуваних зв'язків об'єкта;

- описові гіпотези - передбачення про фактичний стан об'єкта, його структуру, функції;

- пояснювальні гіпотези орієнтовані на визначення причинно-наслідкових зв'язків, виявлення причин, фактів, установлених завдяки підтвердженням описових гіпотез.

При розробці процедурного розділу програми важливо знати, що гарантією цілісного наукового пізнання об’єкта є ретельна розробка методології, методики і техніки дослідження як взаємопов'язаних компонентів. Методологія посідає провідне місце в них, оскільки дає змогу передусім теоретично обгрунтувати вибір методів дослідження, застосування відповідних методик збирання, обробки, аналізу емпіричних даних i вирішення поставленої проблеми. Якщо вихідні методологічні позиції дослідження помилкові, найнадійніші методики не дадуть очікуваного результату. Методика повинна відповідати меті i завданням дослідження, відбивати специфіку об'єкта, що вивчається, сприяти розкриттю кількісних і якісних змін у досліджуваних процесах чи явищах. У процедурному розділі програми даються перелік та характеристика комплексу методів дослідження. Основні з них: анкетуван- ня, інтерв'ю, спостереження, аналіз документів, педагогічний експеримент, хронометрування, контрольні випробування, динамометрія, рефлексометрія, методи лікарського контролю. Визначаються також шляхи дослідження, аналізу та узагальнення матеріалів (способи групування, таблиці, графіки тощо).

В цьому розділі програми визначаються обсяг вибірки, тобто число опитуваних, та методи формування вибірки. Крім опису вибіркової сукупності, визначення типів вибірки, в другому розділі програми накреслюють загальний план та етапи дослідження, дають характеристику методів, які передбачають застосовувати для відбору інформації та іï аналізу, визначають інструментарій і характер очікуваних результатів, роблять узагальнення і дають загальну оцінку результатів, готують підсумкові документи за результатами дослідження.

На даному етапі широко використовуються методи математичної статистики. Для обробки первинних даних застосовуються як елементарні статистики (середнє значення, стандартне відхилення, коефіцієнти асиметрії та ексцесу), так i складні методи багатомірного статистичного аналізу (порівняння векторів середніх значень, класифікація досліджуваних на групи, кореляційний, факторний аналіз). Первісно кожний показник, що вивчається, повинен перевірятися на відповідність закону нормального розподілу.

Для оцінки вірогідності відмінностей між піддослідними за комплексом рухових тестів може використовуватися статистика $\mathrm{T}^{2}$ Хотеллінга. Вибір $\mathrm{T}^{2}$-критерію для порівняння векторів середніх значень досліджуваних показників зумовлюється тим, що показники не є статистично незалежними. Використання ж в цьому випадку одновимірного t-критерію Стьюдента істотно знижує ефективність діагностики. Статистику $\mathrm{T}^{2}$ прийнято розглядати як деяку узагальнену міру відстані між багатомірними середніми двох груп. Про вклад окремо взятої ознаки (без врахування його взаємозв'язку з другими) в узагальнену відстань можна судити по величині одновимірного $\mathrm{T}^{2}$-критерію. Іншими словами, одновимірна $\mathrm{T}^{2}$ статистика є в певному ступені мірою інформативності (розмежувальної спроможності) тієї або іншої ознаки.

Лінійний дискримінантний аналіз використовується для побудови вирішальних правил за навчальними вибірками або, в іншій термінологіï, розпізнання образів «з вчителем». В контексті педагогічної роботи під «образом» розуміється окремий спортсмен, описаний набором рухових характеристик і віднесений до одного 3 класів: «еталонного» або «не еталонного». Вирішальні правила, побудовані на основі лінійних вирішальних функцій, призначені для оптимальної класифікації піддослідних на задані групи. Лі- 
нійні дискримінантні функції можуть розраховуватися як для повного набору характеристик, що вивчаються, так і для скороченого простору інформативних ознак. Для мінімізації комплексу показників використовується процедура послідовного відбору.

Кореляційний аналіз - це процедура для вивчення співвідношення між незалежними змінними. Зв'язок між цими величинами виявляється у взаємній погодженості змін, які спостерігаються. Обчислюється коефіцієнт кореляції. Чим вищим є коефіцієнт кореляції між двома змінними, тим точніше можна прогнозувати значення однієї з них за значенням інших.

Факторний аналіз застосовується для перетворення вхідних факторів до нових змінних, число яких значно менше, а вхідна кореляційна матриця відтворюється 3 достатнім ступенем точності. Завдання факторного аналізу полягає в заміні множини вхідних чинників меншою їх кількістю. 3 точки зору статистики оптимальним $€$ наступний метод: вхідний набір факторів замінюється загальними факторами, визначеними послідовно. Спочатку визначається загальний чинник, який має найбільшу дисперсію. Після цього визначається загальний фактор, який має найбільшу дисперсію $з$ множини факторів, що залишилися. Через кінцеве число кроків-ітерації процес закінчується. Загальні фактори, вклад яких в результуючу величину незначний, визначаються у кінці процесу і можуть бути практично виключені з аналізу. В процесі факторного аналізу необхідно визначити таке число загальних факторів, щоб при мінімальному їхньому числі найбільш точно описати результуючі величини.
Необхідно визначити структуру цих факторів як лінійну комбінацію вхідних.

\section{Висновки:}

1. Упорядкування програми - необхідна умова успішності науково-дослідної роботи. Програма виконує дві функції: науково-пізнавальну i науково-організаційну. Перша забезпечує теоретико-методичну цілісність дослідження, друга - ефективну організацію діяльності наукового колективу.

2. Всі положення програми повинні відповідати логіці дослідження. Розробка програми починається з визначення проблеми, уточнення об’єкта і предмета дослідження і закінчується оформленням іï як окремого документа.

\section{Література}

1. Ашмарин Б.А. Теория и методика педагогических исследований в физическом воспитании. - М.: Физкультура и спорт, 1978. - С. 63-89.

2. Баскаков А.Я., Туленков Н.В. Методология научного исследования. - К.: МАУП, 2002. - С. 73-88.

3. Круцевич Т.Ю. Научные исследования в массовой физической культуре. - К.: Здоров'я, 1985. - С. 30-35.

4. Методы исследования в спорте: Учебное пособие / Под общей редакцией В.П. Филина, А.С. Ровного. - Харьков: Основа, 1992. - С. 63-68.

5. Рудницька О.П., Болгарський А.Г., Свистєльнікова Т.Ю. Основи педагогічних досліджень. - К.: 1998. - 144 с.

6. Шейко В.М., Кушнаренко Н.М. Організація та методика науково-дослідницької діяльності: Підручник. - 2-е вид., перероб. ідоп. - К.: Знання-Прес, 2002. — С. 91-95.

\section{qlobа книжка}

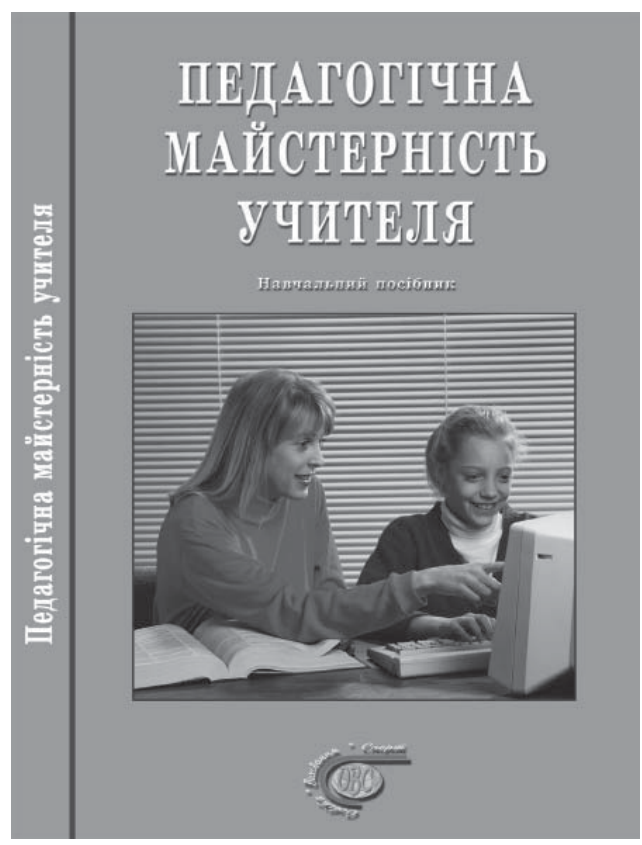

П24 Педагогічна майстерність учителя: Навчальний посібник / За ред. проф. В.М. Гриньової, С.Т. Золотухіної. - Вид. 2-е, випр. і доп. - Харків: «ОВС», 2004. - 224 с. ISBN 966-7858-38-3.

Автори посібника розглядають сутність та структуру педагогічної майстерності вчителя, сформованість якої дозволяє ефективно організовувати навчально-виховний процес у школі.

Посібник укладено у відповідності 3 програмою курсу «Основи педагогічної майстерності» і рекомендується студентам та викладачам вищих педагогічних навчальних закладів. 